\title{
Public-Private Partnership (Ppp) and the Provision of Infrastructure in Nigeria: A Case for Energy Mix Sector in the Niger - Delta
}

\author{
OBUEBITE, Amalate Ann PhD ${ }^{1 *}$, NWOSI-ANELE, Adaobi PhDb ${ }^{2}$, OKWONNA, Obumneme \\ $\mathrm{PhD}^{3}$ \\ ${ }^{I}$ Department of Petroleum Engineering, Niger Delta University, PMB 071, Wilberforce Island, Bayelsa State, Nigeria \\ ${ }^{2}$ Department of Petroleum Engineering, Rivers State University of Science and Technology, PMB 5080, Port \\ Harcourt, Rivers State, Nigeria
}

${ }^{3}$ Department of Chemical Engineering, University of Port Harcourt, PMB 5323, Port Harcourt, Rivers State, Nigeria

*Corresponding Author: OBUEBITE, Amalate Ann PhD, Department of Petroleum Engineering, Niger

Delta University, PMB 071, Wilberforce Island, Bayelsa State, Nigeria

\begin{abstract}
Nigerians expect government to meet their rising energy infrastructural needs. The targets for energy sector development in Nigeria is to increase power generation from the present 20 Gigawatt by 2018 to a projected 350 Gigawatt by 2043 with a focus on increasing existing infrastructure efficiency, expanding transmission networks, decreasing transmission losses, distribution, billing and connection. The paper examined a comprehensive synopsis of public-private partnership (PPP) in the energy-mix sector and presented instances how such partnerships had been implemented in Nigeria. It examined contributions of public-private partnership, infrastructure provision in the Niger Delta energy-mix sector, explored factors that contributed to the ineffectiveness of PPP in Nigeria and recommended solutions. The System theory was adopted to underpin the study. Data from secondary sources were analyzed with the conceptual review method. Review of relevant literatures revealed that the Nigerian government monopolized the energy industry, acting as a policymaker, regulator while owning companies that supply infrastructure services. The energy-mix is the combination of various energy sources used to meet energy demands in a specific location. It consists of fossil fuels. nuclear energy, and renewable energy sources. The study concludes that Nigeria's experience in implementing PPP has not been positive and gives recommendation.
\end{abstract}

Keywords: Public - Private Partnership, Implementation, Infrastructure, Energy Mix, Niger - Delta.

\section{INTRODUCTION}

Building modern, reliable and sustainable infrastructure is critical for meeting the rising aspirations of billions of people around the globe especially in the developing countries. Public infrastructure investment helps raise economic growth rates, offers new economic opportunities and facilitates investment in human capital development. The numbers are stark; about eight hundred (800) million people live without electricity; over 2.2 billion people lack safely managed drinking water service. Congested and inadequate ports, airports, and roadways are a drag on growth and trade (World Bank, 2019).

The decision to comprehensively reform the power sector was taken by the federal government of Nigeria in 2001 following the adaptation of the report of the National Council on Privatization (NCP) steering committee on the electric power sector (Aloke, 2017).The recommendation steering committee were captured in the new national electric power policy. Following the successful completion of the key pillars of the electric power sector reform such as, the vertical and horizontal unbundling of the National Electric Power Authority (NEPA), there was creation of Power Holding Company of Nigeria (PHCN) and its successor companies, transfer of assets to PHCN successor companies and establishment of the industry regulator, the Nigerian Electricity Regulatory Commission (NERC), national council on privatization in 2007 commenced with the process of privatization of the successor companies. The privatization process was successfully completed with the handover of Power Holding Company of Nigeria successor generation and distribution companies to private sector operators on November 1, 2013. 
Public Private Partnership is one of the Public Finance Initiatives (PFIs) and is a contractual agreement between the public and the private sectors to share financial, technical and management risks in project development and management (Olufemi, 2012). It is seen by many as the great formula in infrastructure provision especially with the economic crisis ravaging global economies. Money for pubic project development is now scarce and masses aspiration for projects very high because of globalism and widely use of information technology. A public - private partnership is a tool to get more quality infrastructure services to more people. When designed well and implemented in a balanced regulatory environment, it can bring greater efficiency and sustainability to the provision of public services such as energy, transport, telecommunications, water, healthcare, and education. It also allows for better allocation of risk between public and private entities (World Bank, 2019). Public Private Partnership (PPP) is an alternative form of financing public infrastructure project, the public sector focus on the provision of infrastructure developments at the most cost effective basis, rather than directly owning and operating infrastructures.

Today, Nigeria is seen as one of the greatest developing nations in Africa with highly endowed natural resources including potential energy resources. However, increasing access energy in Nigeria has proved to be not only a continuous challenge but also a pressing with the international community (Odularu and Okonkwo, 2009). Thus, to meet its wing needs of energy, Nigeria must address its persistent energy crisis, which according Iwayemi (2008), has weakened the industrialization process, and significantly undermined the effort to achieve sustained business and economic growth, increased competitiveness of domestic industries in domestic, regional and global markets as well as employment generation.

Energy sectors include the oil and gas as well as the power sub-sectors of Nigeria. It embraces other unconventional sources of energy such as nuclear, solar, wind, biomass among others. It is one of the most important sectors in Nigeria because of its multiplier effect across all sectors of the economy. Its contribution to government revenues and its potentials to spur significant business development are massive. Thus, the energy sub-sector is associated with business development in relation to manufacturing, commerce, infrastructure, skill acquisition, knowledge-based economy, and technology-based investment, agricultural messes, solid minerals and a host of others. Energy is one of the essential sub-sectors that play the most vital role in the overall development of nations. Thus energy consumption has become one of the indices for measuring the standard of living of a country.

It is against this background that this study examined a comprehensive synopsis of the concept of public - private partnership (PPP) in the energy mix sector as well as presents instances of how such partnerships have been developed and implemented in Nigeria and investigates the causes that make PPP ineffective in Nigeria.

\section{Statement of the Problem}

The plight of energy supply in Nigeria has been incessant and deteriorating. Different government in Nigeria, beginning from military era to the current civilian administration, have embarked on energy restructure programme as a means of addressing energy plight in the country, but not much was achieved in spite of huge fund provided for this in the State budget. The Nigeria energy mix sector has shown very low capacity. Transmission and distribution capacity are currently inadequate and inefficient. The fact of the matter is that the privatization programme has faced a lot of plights from the day of handover till date. The plight is seen from four perspectives: governmental, regulatory, consumer and operational (Ogaji, 2017).

The Federal Government of Nigeria made some commitments to the private sector in order to attract private business participation in the provision of energy. It is most unfortunate to report that most of promise went largely unfulfilled. Sound regulation is very vital to the success of the privatized energy sector. Unfortunately, the regulation has been weak in implementation especially in the area cost reflective tariff. On the side of consumers, there is so much impatience for a quick turnaround as neither the government nor the private sector operators had a clear communication strategy to explain to consumers the incremental nature of the gains of the power sector reforms

The study also identified some numbers of plights in implication of public private partnership in the energy mix sector in Nigeria which are technological barriers, economic barriers, and social barriers as the most influential obstacles to public private partnership project operation in Nigeria. 
Consequently, recognition of these plights and its eradication by the investors in public private partnership will allow the partnerships to function effectively and ensuring successful implementation of present-day and impending public private partnership arrangement.

\section{OBJECTIVES OF THE STUdies}

The study examined a comprehensive synopsis of the concept of public - private partnership (PPP) in the energy mix sector as well as presents instances of how such partnerships have been developed and implemented in Nigeria. Specifically, the study examined the contributions of public - private partnership and infrastructure provision in the energy mix sector in the Niger Delta. Also, it explored the factors that contribute to the ineffectiveness of PPP in Nigeria and recommend solutions.

\section{LiTERATURE REVIEW}

Energy generation in Nigeria began in 1896. The Nigerian Electricity Supply Company commenced operations as an electric utility company in Nigeria in 1929 with the construction of a hydroelectric power station at Kurra near Jos. The Electricity Corporation of Nigeria (ECN) was established in 1951, while the first 132KV line was constructed in 1962 linking Ijora Power Station to Ibadan Power Station. The Niger Dams Authority (NDA) was established in 1962 with a mandate to develop the hydropower potentials of the country. Though, ECN and NDA were merged in 1972 to form the National Electric Power Authority (NEPA). In 1998, NEPA ceased to have an exclusive monopoly over electricity generation, transmission, distribution and sales (ECN 2002, ECN, 2005, NPC 2015 \&Ogaji, 2017).

In 1999 - 2000 an Act was enacted by national assembly establishing Power Holding Company of Nigeria (PHCN), an Initial Holding Company (IHC), as a government effort to revitalize energy sector. This was an intended name for which was meant to transfer assets and the liabilities of NEPA to PHCN. It was officially commissioned on the 5th of May 2005 and was to carry out business of NEPA. Similarly, the National Integrated Power Projects (NIPP) was inaugurated in 2004 to be able to catalyzed and fast track the upgrading of adding more capacity to the current available capacity in the country. This was basically a private imitative who is currently being supervised by the Niger Delta Power Holding Company (NDPHC) (ECN 2002, ECN, 2005 NPC 2015 \&Ogaji, 2017).

The PHCN, as a Company, was unbundled into eighteen (18) companies as follows: six (6) generating companies, one (1) transmission company referred to as Transmission Company of Nigeria and eleven (11) distribution companies. The generating companies are Egbin electricity Generating Company (EEGC), Sapele, Ughelli, Afam, Shiroro and Kainji. There are also some new Independent Power Producers under the auspices of the Niger - Delta Power Holding Company (NDPHC). The 11 distribution companies are Abuja Electricity Company (AEDC), Benin Electricity Distribution Company (BEDC), Eko Electricity Distribution Company (EkEDC), Enugu Electricity Distribution Company (ENEDC) Ibadan Electricity Distribution Company (IbEDC), Ikeja Electricity Distribution Company (IkEDC), Jos Electricity Distribution Company (JEDC), Kaduna Electricity distribution Company ( KdEDC), Kano Electricity Distribution Company (KnEDC), Port-Harcourt Electricity Distribution Company (PHEDC), Yola Electricity Distribution Company(PHEDC), Presently, the Federal Government owns 100\% of the transmission company, while its hold on the generating companies is 20 percent (with eighty percent of equity sold to private investors). In other words; the transmission company of Nigeria (TCN) is one hundred (100\%) percent owned, generating companies (GENCOs) 20 percent owned by government and 80 percent private sector ownership. For DISCOs, 60 percent owned by private sector, 40 percent owned by government. (ECN 2002, ECN, 2005 NPC 2015 \&Ogaji, 2017).

The TCN is controlled by the government (nonetheless, the management of TCN is handled by the Canadian company, the Manitoba Hydro Company). On the 30th September 2013, the Federal Government handed over certificates of ownership to prospective owners. As at August 2000, the peak generation was $1,500 \mathrm{MW}$. This was grossly below the demand, which was estimated to be about 4,500MW. The transmission lines were radial and were overloaded. The switchgears were obsolete while power transformers have not been maintained for a long time. The distribution sub-sector was in dire need of upgrading as many of its distribution transformers were overloaded while the lines look more like "Cobwebs", overall transmission and distribution losses were in the range of 30 - 40 $\%$. When these were added to the poor payment record of consumers, collections were less than $50 \%$ of power generated (ECN 2002, ECN, 2005 NPC 2015 \&Ogaji, 2017). 
The forecast load for the year 2001 was 4,833.7MW. In order to meet this demand, a generating capacity of about $6,000 \mathrm{MW}$ was required. Furthermore, the estimated demand for power 2005 and 2010 were respectively $9,780 \mathrm{MW}$ and $20,000 \mathrm{MW}$. These required generating capacities of $12,700 \mathrm{MW}$ and $25,000 \mathrm{MW}$ by the respective years. Thus it was necessary to fully rehabilitate the existing power stations (which was expected to provide a maximum of 5,400MW generating capacity) rehabilitate some critical transmission and distribution lines and their associated substations and add new generating, transmission and distribution capacity to the grid, in the immediate and foreseeable future(ECN 2002, ECN, 2005 NPC 2015 \&Ogaji, 2017).

Meanwhile, Nigeria's Vision 20:2020, recognizes infrastructure, and in particular a reliable energy supply, as vital in achieving sustainable growth and development. To meet the Vision 20:2020 Government set a generating target of $40,000 \mathrm{MW}$. The efficient operation of key government parastatal within the national economy affects even the common citizen. The Major public utilities are parastatal which its workings can be said to form a major part of daily living of most people both at work and at home.

\subsection{Concept of Public - Private Partnership}

There are number of alternative names for PPP as follows: Private Finance Initiative (PFI), a term originating in Britain, and now used in Japan and Malaysia; Private Participation in Infrastructure (PPI), a term coined by the World Bank, however it is little used outside the development - financing sector; P3/3Ps/P3, a term used in North America; Private - Sector Participation (PSP) a term also used in the development - financing sector; and Privately -Financed Projects (PFP) a term used in Australia (Yescombe,2007).

Therefore, there are various PPP models that are used across different countries. A public private partnership is a cooperative business arrangement between two or more public and private sectors, usually of a long - term nature. It involves government(s) and businesses that work together to complete a project and/or to provide services to the people. Public private partnership can cover hundreds of different kinds of long - term contracts with a wide range of risk allocations, funding arrangements, and transparency requirements (Hodge and Greve, 2007).Public Private Partnership (PPP) is a sustained and long - term partnering relationship between the public and private sectors to provide services and goods (Olufemi, 2012).Public-private partnerships involve collaboration between a government agency and private - Sector Company or group of companies that can be used to finance, build, and operate projects, such as public transportation networks, power, energy, health, road, parks, and convention centers (Thomas, 2019).Funding a public project through a public-private partnership can allow a project to be completed sooner or make it a possibility in the first place. The public sector seeks to bring together the resources of the public sector and the technical expertise of the private sectors to provide services and goods to the public at the best value for money (Ministry of Finance, Singapore, 2009).

A Public - Private Partnership is a concept that involves the public and private sectors working in cooperation and partnership to provide infrastructure and services. It is a long-term contractual agreement between a public agency (federal, state/regional or local) and a private sector party to secure the funding, construction or refurbishment, operation and maintenance of an infrastructure project and the delivery of a service that traditionally had been undertaken or provided by the public sector, by sharing of risks and rewards of the venture (Mathieu, 2008; Deep, 2005; Feig \& Finlayson, 2008).

\subsection{Models of Public - Private Partnership}

There are various PPP models that are used across different countries. Categorization of different models of Public - Private Partnership according to Mbanasor and Nwachukwu (2011) and the contractual arrangement between the partners as.

- Build - and - Transfer (BT): In this arrangement, the government provides the financing and construction of the infrastructure and transfers it to the private sector for operation and management.

- Build - Lease - and - Transfer (BCT): In this arrangement, the private party finances and constructs the infrastructure and then hands it over to the government agency for management on a lease basis 
- Build - Own - Operate (BOO): In this arrangement; the private party is authorized to finance, construct, own and operate an infrastructure project, and is allowed to recover both the acquisition and operating expenses by charging levies over a specified period.

- Build-Operate-and-Transfer (BOT): In this arrangement, the government provides the financing and construction of the project, operates and maintains theproject over a fixed period of time and charges levies for the use. At the end of the period, it transfers the project to the private sector

- Built - Transfer - and - Operate (BTO): In this arrangement, the government agency arranges for the private party to build the infrastructure project on a turn-key basis, so that upon completion the private party is given the right to operate the facility and collect levies there from

- Contract-Add - and - Operate (CAO): This is an arrangement in which the private party expands an existing infrastructure facility which it has leased from a government agency. The private party operates the expanded facility and collects user levies there from

- Rehabilitate - Operate - and - Transfer (ROT): In this arrangement, the private party takes over an existing facility, refurbishes it, then operates and maintains it for a specified period during which he charges user levies

- Rehabilitate-Own-and-Operate (ROO): In this arrangement, the existing facility is taken over by a private party, then refurnishes, operates and maintains the facility with no time limitation and charges user levies on the facility

- Concession Agreement (CA): Is a collaborative arrangement between a government and private developer/s to design and develop facilities through combination of participants which include the financiers and the contractors and or consultants. itisalso arrangement, the private party acquires the operation and management of an infrastructure project for a specified consideration. The government agency collects the user levies

- Management Contract (MC): In this arrangement, the government agency hands over the operation and management of infrastructure facility for an agreed period on the payment of a consideration.

- Service Contract (SC): In this arrangement, the private party undertakes to provide specified services to a government agency for a specified period in terms of an infrastructure facility.

Table1. Defining Characteristics of the Various Public Private Partnership Models

\begin{tabular}{|l|l|l|}
\hline PPP Type & Explanation & $\begin{array}{l}\text { Life } \\
\text { Contract }\end{array}$ \\
\hline Service Contract (SC) & $\begin{array}{l}\text { Public sector entrusts private companies with providing some services } \\
\text { provided traditionally by government such as maintenance of } \\
\text { equipment and/or cleaning services and payment for these services are } \\
\text { according to contract }\end{array}$ & 1 Years \\
\hline $\begin{array}{l}\text { Management Contract } \\
\text { (MC) }\end{array}$ & $\begin{array}{l}\text { Public sector entrusts private companies with operating infrastructure } \\
\text { or providing management services according to contract }\end{array}$ & 3-5 Years \\
\hline $\begin{array}{l}\text { Design - Build } \\
\text { Transfer (DBT) }\end{array}$ & $\begin{array}{l}\text { Private sector designs and builds infrastructure and bears the risks of } \\
\text { extension and any additional costs-the standards and the price are set in } \\
\text { advance-assets are finally transferred to the public sector }\end{array}$ & Variable \\
\hline $\begin{array}{l}\text { Design - Build -Major } \\
\text { Maintenance (DBMM) }\end{array}$ & $\begin{array}{l}\text { Public sector is responsible for the management of the infrastructure } \\
\text { designed and built by the private companies who are also responsible } \\
\text { for major maintenance }\end{array}$ & Variable \\
\hline $\begin{array}{l}\text { Operation and } \\
\text { Maintenance (OM) }\end{array}$ & $\begin{array}{l}\text { Public sector signs agreement with the private sector that will be } \\
\text { responsible for operation and maintenance of infrastructure according } \\
\text { to contract. Payment is through fees from government }\end{array}$ & Years \\
\hline $\begin{array}{l}\text { Design Build Operate } \\
\text { (DBO) }\end{array}$ & $\begin{array}{l}\text { Private companies design build and operate infrastructure projects } \\
\text { although ownership remains with the government }\end{array}$ & Variable \\
\hline $\begin{array}{l}\text { Lease-Upgrade- Operate } \\
\text { Transfer (LUOT) }\end{array}$ & $\begin{array}{l}\text { Infrastructure is leased and operated for a certain period by a private } \\
\text { company over which it can be upgraded and extended before transfer to } \\
\text { the public sector at the end of the contract }\end{array}$ & 8-15 years \\
\hline
\end{tabular}


Public-Private Partnership (Ppp) and the Provision of Infrastructure in Nigeria: A Case for Energy Mix Sector in the Niger - Delta

\begin{tabular}{|l|l|l|l|}
\hline $\begin{array}{l}\text { Purchase, Upgrade, } \\
\text { Operate } \\
\text { (PUOT) }\end{array}$ & $\begin{array}{l}\text { Private companies operate the infrastructure which will be } \\
\text { upgraded/extended and possess ownership during the contract which is } \\
\text { transferred to the public sector at the contract's end }\end{array}$ & 8 years \\
\hline $\begin{array}{l}\text { Build lease Operate, } \\
\text { Transfer (BLOT) }\end{array}$ & $\begin{array}{l}\text { A long run lease is signed between the public and private sectors. } \\
\text { Infrastructure is built by private companies on public land and operated } \\
\text { until the private capital is recovered through fees from users. At the } \\
\text { end, ownership is transferred to the public sector }\end{array}$ & $\begin{array}{l}25-30 \\
\text { years }\end{array}$ \\
\hline $\begin{array}{l}\text { Build, Own, Operate, } \\
\text { Transfer (BOOT) }\end{array}$ & $\begin{array}{l}\text { Private companies invest, build and operate and own infrastructure } \\
\text { until capital is recovered through fees under a concession from the } \\
\text { government }\end{array}$ & $25-30$ years \\
\hline $\begin{array}{l}\text { Design, Build, Transfer, } \\
\text { Operate(DBT) }\end{array}$ & $\begin{array}{l}\text { Infrastructure is invested in and built by the private sector and } \\
\text { transferred to the government at a pre-agreed price. It is then leased and } \\
\text { operated by the private sector who through this arrangement avoid } \\
\text { ownership risks }\end{array}$ & $25-30$ \\
years \\
\hline $\begin{array}{l}\text { Design Build Finance, } \\
\text { Operate (DBFO) }\end{array}$ & $\begin{array}{l}\text { Private sector invests and establishes the asset. Public sector provides } \\
\text { core services to the asset and private sector provides related services } \\
\text { e.g. a hospital }\end{array}$ & $25-30$ years \\
\hline $\begin{array}{l}\text { Purchase } \\
\text { Operate (PUO) }\end{array}$ & $\begin{array}{l}\text { Private sector purchases, operates and upgrades assets with view to } \\
\text { permanent ownership and the end of the contract under government } \\
\text { supervision }\end{array}$ & Permanent \\
\hline $\begin{array}{l}\text { Build Own Operate } \\
\text { BOO) }\end{array}$ & $\begin{array}{l}\text { Private sector invests, builds and permanently owns asset under terms } \\
\text { that secure public interest under government supervision }\end{array}$ & Permanent \\
\hline
\end{tabular}

Source: Adopted from Oluoch \&Wainainai (2010).

\subsection{Benefits of Public Private Partnerships in Nigeria}

- Exploring Public Private Partnership as a method of introducing private sector technology and innovation in providing better public services through improved operational efficiency

- Incentivizing the private sector to deliver projects on time and within budget framework

- Imposing budgetary confidence by setting present and the future costs of infrastructure projects over time

- Employing Public Private Partnership as a mode of developing local private sector capabilities through joint ventures with large international firms, as well as sub-contracting opportunities for local firms in areas such as civil works, electrical works, facilities management, security services, cleaning services, maintenance services.

- Using Public Private Partnership as a technique of gradually exposing state owned enterprises and government to increasing levels of private sector participation (especially foreign) and structuring Public Private Partnership in a way so as to ensure transfer of skills leading to national champions that can run their own operations professionally and eventually export their competencies by bidding for projects/ joint ventures.

- Creating personification in the economy by making the country more competitive in terms of its facilitating infrastructure base as well as giving a boost to its business and industry associated with infrastructure development (such as construction, equipment, support services)

- Supplementing limited public sector capacities to meet the growing demand for infrastructure development.

- Extracting long-term value-for-money through appropriate risk transfer to the private sector over the life of the project - from design/ construction to operations/ maintenance.

\subsection{Risks of Adoption of Public Private Partnerships in Nigeria}

There are several potential risks connected with the adoption Public Private Partnerships in Nigeria.

- Development, bidding, and ongoing costs in Public Private Partnership projects are likely to be greater than for traditional government procurement processes - the government should therefore determine whether the greater costs involved are justified. Quite several of the Public Private Partnership arrangement and its implementation units around the World have developed methods for analyzing these costs and looking at value for money. 
- There is a cost attached to debt while private sector can make it easier to get finance, finance will only be available where the operating cash flows of the project company are expected to provide a return on investment.

- Some projects may be easier to finance than others (if there is proven technology involved and/or the extent of the private sectors obligations and liability is clearly identifiable), some projects will generate revenue in local currency only; for instance, water projects while others like ports and airports will provide currency in dollar or other international currency and so constraints of local finance markets may have less impact

- Some projects may be more politically or socially challenging to introduce and implement than others - particularly if there is an existing public sector labour force that fears being transferred to the private sector, if significant tariff increases are required to make the project viable, if there are significant land or resettlement issues, etc.

\subsection{Energy Mix}

Energy mix refers to the combination of the various primary energy sources used to meet energy needs in a given geographic region. It includes fossil fuels (oil, natural gas and coal), nuclear energy and the many sources of renewable energy (wood and other bio-energies, hydro, wind, solar and geothermal). These primary energy sources are used, for example, for generating power, providing fuel for transportation and heating and cooling residential and industrial buildings. The composition of the energy mix varies greatly from one country to the next and can change significantly depending on the period.

\subsection{Energy Mix Sources in Nigeria}

Oil: crude oil was discovered in commercial quantities in Nigeria in 1956 while oil production started in 1958. Nigeria had a proven reserve estimate of about 32 billion barrels of predominantly low sulphur light crude, as of January 2002. Oil will continue to play a major role in the nation's economy. Oil is used to create transportation fuels such as gasoline, diesel and jet fuel. It's also used for heating, and as a feedstock for petrochemicals which are used to create many products, we use every day.

Natural Gas: Nigeria's proven natural gas reserves, estimated at about 163 trillion standard cubic feet, are known to be substantially larger than its oil resources in energy terms. Natural gas has a variety of uses including transportation, as a feedstock for petrochemical industries, and electricity generation. Gas originates in the Niger Delta area.

Tar Sands: These exist in Nigeria and the deposit is preliminarily estimated to contain a total reserve of about 30 billion barrels of oil equivalent. Tar sands can be refined similarly to heavy crude.

Coal: is used mainly for two purposes, steelmaking and power generation. Available data show that coal of sub-bituminous grade occurs in about 22 coal fields spread in over 13 states of the Federation. Proven coal reserves so far in the country are about639 million tonnes while the inferred reserves are about 2.75 billion tonnes, consisting approximately $49 \%$ sub-bituminous, $39 \%$ bituminous and $12 \%$ lignitic coals.

Nuclear: nuclear energy is one of the major sources of base load electricity generation in the world today.

Hydropower: is produced when water is stored in a reservoir behind a dam. Pumped storage is another type of hydro, where water is pumped up to an elevated reservoir for storage. When electricity generation is required, the water is released. At run-of-river facilities, water in a river directly spins a turbine to generate electricity. Hydropower is one of the major sources of base load electricity generation. Despite its high initial capital cost, hydropower provides one of the cheapest and cleanest sources of electricity. Nigeria is well endowed with large rivers and natural falls with good hydropower potentials.

Solar: Solar technologies use the sun's energy to heat homes and water and generate electricity. The quantity of available solar energy varies depending on the season, weather and the technology is used to harness the sunlight. solar energy can be harnessed as a source of electricity, which is clean and renewable. Nigeria lies within a high sunshine belt, where solar radiation is well distributed. 
Public-Private Partnership (Ppp) and the Provision of Infrastructure in Nigeria: A Case for Energy Mix Sector in the Niger - Delta

Biomass: is a biological material in solid, liquid or gaseous form that has stored sunlight in the form of chemical energy, such as wood, peat and agricultural byproducts. There is a large potential for biomass energy in Nigeria.

Wind: turbine generation is another developing energy source in Nigeria. The annual average wind speed at $10 \mathrm{~m}$ height varies from $2 \mathrm{~m} / \mathrm{s}$ in the coastal areas to about $4 \mathrm{~m} / \mathrm{s}$ in the far northern region of Nigeria. Thus, potential wind power is abundant.

Geothermal: is a source of energy that is captured from the heat stored beneath the earth's surface.

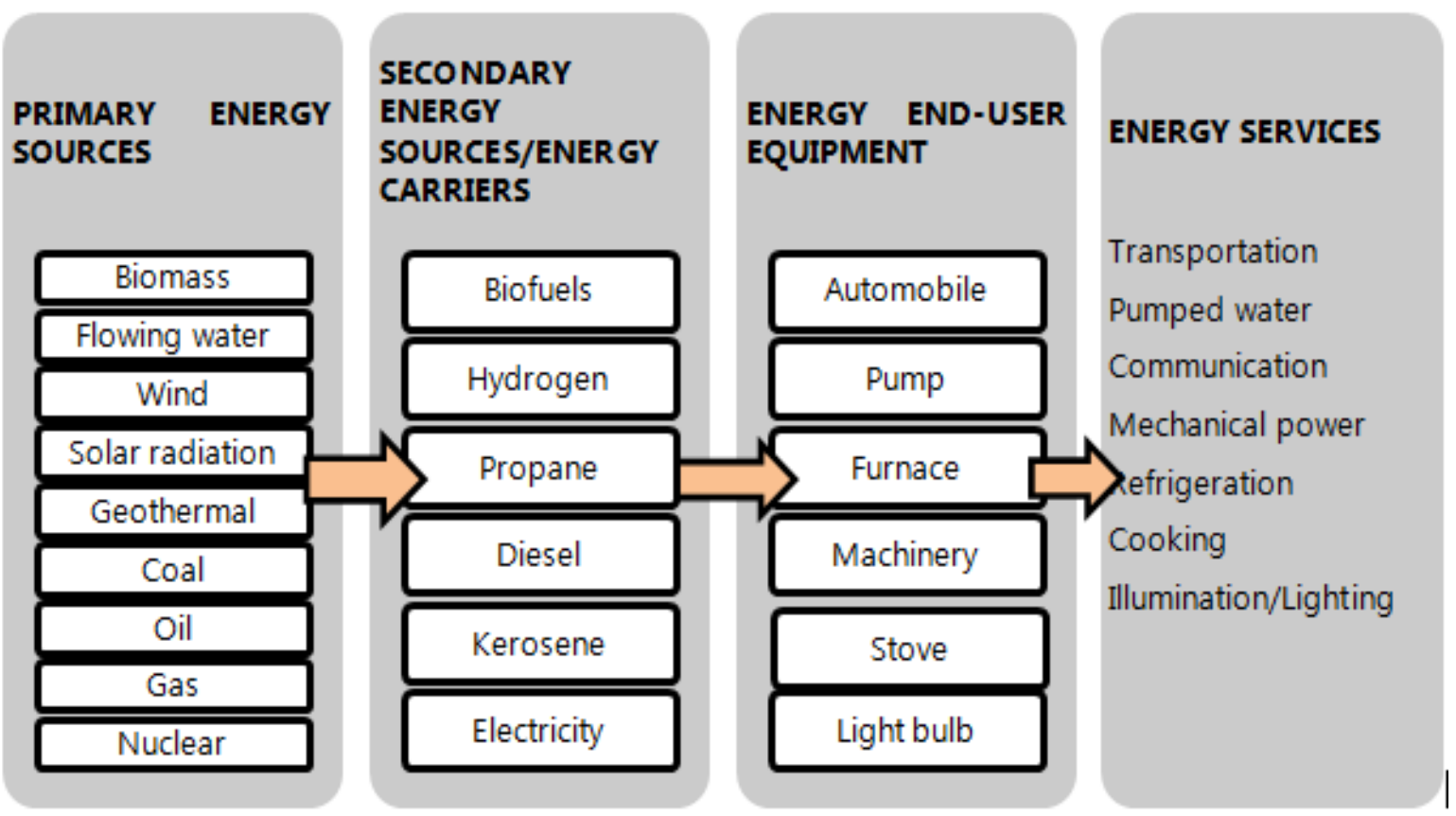

Figure1. The Energy Chain (UNDP, 2005)

\subsection{Market Design for Electricity in Nigeria}

The Nigeria market is expected to evolve through the following stages:

Pre - Transitional Stage: This is characterized by inadequate and unreliable supply of electricity.

Transitional Stage: This is characterized by demand exceeding supply; all trading is made through contract; the conditions and prices of vesting contracts are not freely negotiated; there are transparent and competitive mechanisms for entering in the market.

Medium Term Stage: This stage is characterized by competition to enter into the market to supply; contracts can be negotiated freely and power can be traded like a commodity (financial contracts); there is a centralized merit order dispatch (energy at least cost is dispatched first) by the system operator, where generators must submit the dispatch nomination (availability, constraints, costs/prices) to be used in the security constrained economy (least cost) dispatch.

Long Term Stage: This stage is like the medium-term stage but characterized by more competition and greater freedom by eligible consumers to choose their suppliers/distributor.

\subsection{Theoretical Framework}

The System theory was adopted to underpin the study. Systems theory was proposed in the 1940s by biologist Ludwig von Bertalanffy, say Francis Heylighen and Cliff Joslyn in their article, "What is Systems Theory," published on Principia Cybernetica. Heylighen and Joslyn note: (Von Bertalanffy) emphasized that real systems are open to and interact with their environments and that they can acquire qualitatively new properties through emergence, resulting in continual evolution. Rather than reducing an entity ... to the properties of its parts or elements ... systems theory focuses on the arrangement of and relations between the parts which connect them into a whole. This particular organization determines a system, which is independent of the concrete substance of the elements (Leon, 2018). 
In business operation, a system theory of organization refers to the way a part of a company or organization interacts with the organization, or even with the market or industry as a whole. Even though the theory started in biology, the application of system theory has a profound role in business. Put another way, the current use of system theory in business defines a potential way to explain the workings of any corporation or organization.

\section{Methodology}

The study adopted previous research studies and documentary reports as a means of identifying the plights and/or barriers to public - private partnership in the energy mix sector as well as presents instances of how such partnerships have been developed and implemented in Nigeria. Data were obtained from secondary sources and analyzed with the conceptual review method.

\section{DISCUSSION}

Nigeria's huge infrastructure deficit remains a major problem to better living standards, enterprise development and sustained economic growth. Midst numerous financing models, public - private partnerships present a preferred window for long term infrastructure provision and development adopted by many nations worldwide. Over the years, Nigeria has experienced poor execution of public - private partnership projects caused by fundamental bottlenecks such as lack of strategic direction for infrastructure, weak political will, political interests/interference, lack of transparency and weak legal and regulatory frameworks among others.

Energy sector reform was meant to create platform that would foster choice and competitive power markets supervised by the Nigerian Electricity Regulatory Commission (NERC) which is constituted to provide a credible and effective regulatory process that would monitor overall market performance to detect and correct market design flaws. Energy is indispensable in its drive at fixing all economic activities. Greater energy consumption guarantees more economic activities in Nigeria, and access to energy in Nigeria has proved to be inadequate in proportion to its residential and industrial demand. This has been a pressing issue national discourse as it is interdependent and prerequisite for the country to advance. The greater the energy supply in Nigeria, the greater potential for business activities, economic growth and improved productivity growth and improved productivity. This study looks at the experiences of public - private partnership while reviewing critical challenges and proffering solutions to making public - private partnership work in Nigeria.

\section{CONCLusions}

The energy sector is critical to the growth and development of the Nigerian economy in several respects. Its management has however posed the most unnerving challenge over the years. Under the management of the National Electric Power Authority (NEPA) was an inefficient monopoly where provision of service was grossly incompetent. The reform in the sector was aimed at breaking the monopoly by deregulating the sector and opening it up to private sector participation in a competitive market environment. To achieve this, the national council on privatization and bureau of public enterprise developed and produced a policy. The reform brought about fundamental changes which unbundling national electric power authority into six generating companies, eleven distribution companies and one transmission company. The establishment of the Nigerian electricity regulatory commission and the development of competitive electricity market rules and pricing system. There was creation of Power Holding Company of Nigeria (PHCN) and its successor companies, transfer of assets and liabilities of the former national electric power authority to PHCN successor companies. The privatization process was successfully completed with the handover of power holding company of Nigeria successor transmission, generation and distribution companies to core private investors on November 1, 2013.

\section{RECOMMENDATIONS}

- Nigeria government cannot be said to have been effective in the discharge of its responsibility when majority of the people are still suffering from inadequate energy supply. The infrastructure gap in the provision of so energy supply in Nigeria is very wide; these realities dictate that alternative models in infrastructure provision at all level of government should be identified and used to strengthen and improve infrastructural deficit. 
- There should more determination by the government about security of supply of gas associated with resource control agitation in the Niger Delta region.

- Government should ensure that disco performance and removal of operators who fail to perform in line with the performance.

- The study recommends that in the choice of public - private partnership partners, the government should consider the cost of financing a project through negotiations and the duration for financing. This will help in reducing the cost of public - private partnership while promoting development in the energy sector.

\section{REFERENCES}

[1] Aloke, A. (2017). Is the power sector recovery plan the panacea for resolving the challenges of the power sector? Privatization Digest Journal of the Bureau of Public Enterprise, December.

[2] Deep, A. (2005). Public - private partnerships for financing of infrastructure development. Harvard University, December.

[3] Energy Commission of Nigeria (2002). National energy policy. Abuja, August.

[4] Energy Commission of Nigeria (2005). Renewable energy master plan. Abuja, November.

[5] Feig, H. and Finlayson, B. (2008). Special evaluation study on ADB assistance to public private partnerships in infrastructure development, 13 March.

[6] Hodge, G. A. and Greve, C. (2007), Public - private partnerships: an international performance review. Public Administration review, Vol. 67(3), pp. 545-558

[7] Iwayemi, A. (2008). Nigeria's dual energy problems: policy issues and challenges. International Association for Energy Economics, 1st IAEE International Conference, Istanbul, Turkey, June 18-20, 2008.

[8] Leon, T. (2018). Application of systems theory in business organizations.

[9] Mathieu, N. (2008), EBRD's Past experience from public private partnerships operations, lessons learned and recommendations, workshop on evaluation and public private partnerships, AfDB, Tunis, 24-25 April.

[10] Ministry of Finance, Singapore (2009) Public Private Partnerships. Available at http://www.mof.gov.sg/ policies/ppp.html.

[11] National Planning Commission (2015). National integrated infrastructure master plan. Retrieved from http://www.nationalplanning.gov.ng/images/docs/National\%20Intergrated\%20Infractructure\%20 Master\%20Plan.pdf

[12] Odularu, G. O. and Okonkwo, C. (2009). Does energy consumption contribute to economic performance? Empirical evidence from Nigeria. East- West Journal of Economics and Business, Vol.12(2), 37-79.

[13] Olufemi A. O. (2012). Public-private partnership (PPP) and infrastructure provision in Nigeria. Conference Paper.

[14] Oluoch andWainainai (2010).

[15] Ogaji, J. (2017). Transparency and visibility of market funds: a panacea to NESI efficiency. Privatisation Digest Journal of the Bureau of Public Enterprise, December, 2017.

[16] Thomas, B. (2021). Public-private partnerships. The Investopedia.

[17] Thomas, B. (2019). Public-private partnerships. The Investopedia.

[18] UNDP (2005), Energizing the Millennium Development Goals: A Guide to Energy's Role in Reducing Poverty, New York, August.

[19] World Bank (2019). Public-private partnership units: lessons for their design and use in infrastructure, World Bank/PPIAF, Washington, D. C.

[20] Yescombe, E. R. (2007) Public-private partnerships: principles of policy and finance, $1^{\text {st }}$ edition, Elsevier Science, Oxford

Citation: OBUEBITE, Amalate Ann PhD, et.al (2021). "Public-Private Partnership (Ppp) and the Provision of Infrastructure in Nigeria: A Case for Energy Mix Sector in the Niger - Delta", International Journal of Petroleum and Petrochemical Engineering (IJPPE), 7(1), pp.11-20. DOI: https://doi.org/10.20431/24547980.0701002

Copyright: () 2021 Authors, This is an open-access article distributed under the terms of the Creative Commons Attribution License, which permits unrestricted use, distribution, and reproduction in any medium, provided the original author and source are credited. 